\title{
Feed training of giant trahira fingerlings fed diets containing different levels of vitamin C
}

\author{
Rodrigo Yutaka Dichoff Kasai ${ }^{1}$, Ana Lúcia Salaro ${ }^{1}$, Jener Alexandre Sampaio Zuanon ${ }^{1}$, \\ Céphora Maria Sabarense ${ }^{1}$, Mateus Moraes Tavares ${ }^{1}$, Daniel Abreu Vasconcelos Campelo ${ }^{1}$ \\ 1 Universidade Federal de Viçosa, Campus Universitário, Departamento de Biologia Animal, Setor de Piscicultura - $36570-000$ - Viçosa, MG, \\ Brasil.
}

ABSTRACT - The objective of this work was to evaluate suplemenation of vitamin C during feed training of giant trahira fingerlings. An experiment was established in a complete random design with seven treatments $(0.0,17.5,52.5$, 87.5, 122.5, 175.0 and $350.0 \mathrm{mg}$ vitamin $\mathrm{C} / \mathrm{kg}$ diet $)$ and four repetitions. Giant trahira fingerlings $(2.8 \pm 0.2 \mathrm{~cm})$ were distributed in 6-L aquaria at the density of 6 fish/L. A basal diet was formulated with $44.0 \%$ of crude protein and vitamin $\mathrm{C}$ and bovine heart were added in it daily. After 20 days, biometry of fish for evaluation of weight and length gains, rates of survival and cannibalism and uniformity of final length and for macroscopic observations of clinical signs of deficiency or excess of vitamin was carried out. After biometry evaluation, ten fish from each tested diet were collected for analysis of the fatty acid profile which was compared to profile of fish at the same life stage fed forage fish collected from breeding fishponds. Data on growth performance and fatty acid profiles were submitted to analyses of polynomial regression and uniformity of the final length was evaluated by the Bartlett test. There was a significant difference only for uniformity in final length and fatty acid profile of the carcass. Supplementation with $52.5 \mathrm{mg}$ vitamin $\mathrm{C} / \mathrm{kg}$ diet provided a greater uniformity of the final length of the fish. Fish from breeding fishponds presented lower concentration of PUFA (polyunsaturated fatty acids) and higher concentration of saturated fatty acids compared to fish trained to accept dry diets.

Key Words: cannibalism, carnivorous fish, Hoplias lacerdae, length uniformity, lipid profile

\section{Condicionamento alimentar de alevinos de trairão com dietas contendo diferentes níveis de vitamina C}

RESUMO - Com este trabalho objetivou-se avaliar a suplementação de vitamina C durante a fase de condicionamento alimentar de alevinos de trairão. Um experimento foi estabelecido em delineamento inteiramente casualizado com sete tratamentos $(0,0 ; 17,5 ; 52,5 ; 87,5 ; 122,5 ; 175,0$ e 350,0 $\mathrm{mg}$ de vitamina $\mathrm{C} / \mathrm{kg}$ de ração) e quatro repetições. Alevinos de trairão $(2,8 \pm 0,2 \mathrm{~cm})$ foram distribuídos em aquários de $6 \mathrm{~L}$, na densidade de 6 peixes/L. Uma ração basal foi confeccionada com 44,0\% proteína bruta, e diariamente foi adicionada vitamina C e coração bovino. Após 20 dias, realizou-se biometria dos peixes para avaliação do ganho de peso e do comprimento, das taxas de sobrevivência e canibalismo e da uniformidade do comprimento final e para observações macroscópicas de sinais clínicos de deficiência ou excesso da vitamina. Após a biometria, dez peixes de cada dieta testada foram coletados para análise do perfil de ácidos graxos e este perfil foi comparado ao perfil de peixes, na mesma fase de vida, alimentados com peixes forrageiros coletados de viveiros de criação. Os dados de desempenho produtivo e perfil de ácidos graxos foram submetidos a análise de regressão polinomial e a uniformidade do comprimento final avaliada pelo teste de Bartlett. Houve diferença significativa apenas para a uniformidade em comprimento final e perfil de ácidos graxos da carcaça. A suplementação com 52,5 mg de vitamina C/kg de ração proporcionou maior uniformidade do comprimento final dos peixes. Os peixes dos viveiros de criação apresentaram menor concentração de PUFA (polyunsaturated fatty acids) e maior de ácidos graxos saturados em comparação aos peixes condicionados a aceitar dietas secas.

Palavras-chave: canibalismo, Hoplias lacerdae, peixes carnívoros, perfil lipídico, uniformidade em comprimento

\section{Introduction}

The giant trahira (Hoplias lacerdae Ribeiro, 1908) is a carnivorous species with good adaptation to captive conditions, hardiness and high weight gain, which allows for captive breeding of this species. During captive breeding of carnivorous species, there is a need for feed training, i.e. the replacement of natural food diets by dried and 
processed food. During this process, the constant change of diet can be a stressor for fish (Barcellos et al., 2000). However, stress can be relieved by controlling the diet inasmuch as the physiological state of an animal is a reflection of the quality and quantity of available nutrients in the diet (Falcon et al., 2007a). Among the nutrients used in diets to reduce the effects of stress on fish, vitamin $\mathrm{C}$ acts as an antioxidant eliminating free radicals (Lall and Lewis-McCrea, 2007), reducing stress and promoting comfort for the animal (Li \& Lovell, 1985; Sakakura et al., 1998; Petric et al., 2003; Moraes et al., 2003; Wang et al., 2006). It also participates in the synthesis of carnitine (Chien \& Hwang, 2001), which is fundamental in the transport of long chain fatty acids into mitochondria, favoring the production of energy (Bilinski \& Jonas, 1970). The supply of dietary vitamin $C$ may also regulate the activity of lysoenzymes and immunoglobulin concentrations in blood plasma, increasing the immune responses of the animal (Ren et al., 2008, Lim et al., 2010).

Unfavorable conditions increase demand for vitamins, especially vitamin C (Wedemeyer, 1969; Navarre \& Halver, 1989, Falcon et al., 2007b). In carnivorous fish, stressful situations are common due to the high degree of cannibalism. Stress triggers a series of physiological mechanisms that require energy (Barton \& Iwama, 1991) and mobilization of reserves (Deboeck et al., 2000). Therefore, fish under stressful conditions may have an increased demand for vitamin C (Wedemeyer, 1969; Navarre \& Halver 1989).

Deficiency of vitamin C can cause abnormal growth and development of animals (Steffens, 1989; Al-Amoundi et al. 1991; Tacon, 1992; NRC, 1993; Wang et al., 2003). An excess can also impair the performance of fish, as observed in catfish fingerlings of the species Pseudoplatystoma corruscans (Fujimoto \& Carneiro, 2001). In contrast, diets with adequate levels of vitamin $\mathrm{C}$ may result in better performance of fish (Okorie et al. 2008; Lin \& Shiau, 2005).

Considering the occurrence of stress caused by changes in diet and the possibility of cannibalism during food training, an experiment was carried out to evaluate the effects of vitamin $\mathrm{C}$ supplementation in the diets of giant trahira fingerlings.

\section{Material and Methods}

The experiment was conducted at the Laboratório de Nutrição de Peixes do Setor de Piscicultura do Departamento de Biologia, Universidade Federal de Viçosa (UFV), Viçosa, over a period of 20 days using a randomized design with seven treatments $(0.0,17.5,52.5,87.5,122.5$, 175.0 and $350.0 \mathrm{mg}$ vitamin $\mathrm{C} / \mathrm{kg}$ diet) and four replications.
Giant trahira fingerlings with a standard length of $2.8 \pm 0.2 \mathrm{~cm}$ and weight of $0.36 \pm 0.06 \mathrm{~g}$ were assigned to 28 aquaria $(35 \times 30 \times 14 \mathrm{~cm})$ containing $6 \mathrm{~L}$ of salt water $(4.0 \mathrm{~g}$ of salt per liter of water), with a temperature of $25^{\circ} \mathrm{C}$ and constant aeration, at a stocking density of six fish/L. The aquaria were covered with plastic screens to prevent the escape of fish.

A basal diet was formulated according to the chemical composition of the ingredients described by Rostagno et al. (2005) (Table 1) and free vitamin supplement plus vitamin C. This ration was mixed with vitamin $\mathrm{C}$ and bovine heart daily. As a source of vitamin C, ascorbyl monophosphate with a composition of $35.0 \%$ active ingredient was used. The chemical composition of the basal diet and bovine heart was determined at the Laboratório de Análise de Alimentos do Departamento de Nutrição e Saúde da Universidade Federal de Viçosa, at UFV (Table 2).

During the experimental period, fingerlings were fed wet food in the form of pellets, baked with heart meat for animals for five days to adapt to the laboratory conditions. Fish feed training was performed by a transition from the wet diet to a dry one according to the model proposed by Luz et al. (2002), with modifications, varying only the number of days in each phase of the training (Table 3). The fish were fed ad libitum at 7:00 a.m., 11:30 a.m. and 4:30 p.m. At 6:00 p.m., the aquarium was cleaned by replacing all the water and restoring the same salinity.

Table 1 - Composition of ingredients used in the basal diet

\begin{tabular}{lr}
\hline Ingredient (\%) & Basal diet \\
\hline Soybean meal & 24.80 \\
Fish meal & 52.00 \\
Corn meal & 5.68 \\
Wheat bran & 14.70 \\
DL-methionine & 0.35 \\
Soybean oil & 2.00 \\
Salt & 0.25 \\
Mineral supplement & 0.10 \\
Vitamin supplement (without C vitamin) & 0.10 \\
Butylated-hidroxy-toluene (antioxidant) & 0.02 \\
Calculated composition & \\
Gross energy (kcal/kg) & 4304.10 \\
Crude protein (\%) & 44.00 \\
Crude fiber (\%) & 3.08 \\
Ether extract (\%) & 6.06 \\
Total calcium (\%) & 2.43 \\
Available phosphorus (\%) & 0.99 \\
Methionine (\%) & 1.02 \\
Lysine (\%) & 2.13 \\
Gross energy/crude protein & 97.82 \\
\hline 1 Gross levels of guarantee, calculated based on the diet, vitamin and mineral \\
supplement (Mogiana Alimentos S/A - GUABI): A vit. - 16,000UI; D vit. - \\
4,500 UI; E vit. - 250 mg; K vit. - 30 mg; B1 vit. - 32 mg; B2 vit. - 32 mg; \\
B12 vit. - 32 mcg; B6 vit. - 32 mg; C vit. - zero; pantothenic acid - 80 mg; niacin - \\
170 mg; biotin - 10 mg; folic acid - 10 mg; colin - 2,000 mg; cobalt - 0.5 mg; \\
copper - 20 mg; iron - 150 mg; iodine - 1 mg; manganese - 50 mg; selenium - \\
1 mg; zinc - 150 mg; antioxidant additive - 150 mg. \\
$\quad$ ing
\end{tabular}

R. Bras. Zootec., v.40, n.3, p.463-468, 2011 
Table 2 - Chemical composition of basal diet and bovine heart (g/100 g of sample)

\begin{tabular}{lccccc}
\hline Product & Moisture & Lipid & Crude protein & Ash & Carbohydrates $^{1}$ \\
\hline Ration & 7.18 & 8.29 & 44.21 & 15.81 & 24.51 \\
Bovine heart & 80.04 & 1.14 & 16.85 & 0.98 & 0.99 \\
\hline
\end{tabular}

1 The carbohydrate content was estimated by the fraction NIFEXT (nitrogen-free extract) calculated by the difference between the sum of the measures taken and the total mass of the sample.

Table 3 - Percentage of the mixture (bovine heart and ration) and number of days of supply of test diets used in the training of giant trahira fingerlings

\begin{tabular}{ccc}
\hline Phases & Composition & Days \\
\hline 1 & $80 \%$ bovine heart $+20 \%$ diet & 4 \\
2 & $60 \%$ bovine heart $+40 \%$ diet & 4 \\
3 & $40 \%$ bovine heart $+60 \%$ diet & 4 \\
4 & $20 \%$ bovine heart $+80 \%$ diet & 4 \\
5 & $100 \%$ diet \\
\hline
\end{tabular}

At the end of the training phase (20 days), the fingerlings were counted, measured and weighed to assess weight gain, the uniformity of length and rates of survival and cannibalism. The initial and final uniformity were evaluated by the coefficient of variation of the initial length and final length, respectively. For biometrics, the animals were assessed macroscopically to detect possible signs of deficiency or excess of vitamin $C$ as for example body deformity (lordosis), malformation of the operculum and mouth, erosion of fins and presence of hemorrhagic exophthalmos.

After biometry, 10 fry from each treatment were euthanized on ice and stored in a freezer $\left(-80^{\circ} \mathrm{C}\right)$ for later determination of the fatty acid profile. A group of fish at the same stage of development, not submitted to feed training, was collected from the cultivation tank to be compared with the fatty acid profile of the conditioned fish. The giant trahira fingerlings were placed together with Nile tilapia (Oreochromis niloticus) fingerlings as forage fish.

The determination of the fatty acid profile was performed at the Laboratório de Análise de Alimentos do Departamento de Nutrição e Saúde da Universidade Federal de Viçosa, at UFV, where the fish from each treatment were homogenized and samples were separated in triplicate for extraction (Folch et al., 1957) and derivatization (Hartman \& Lago, 1973) of lipids.

The profile of fatty acids was identified by gas chromatography using a gas chromatograph Shimadzu GC 17/ GC 10 Class, equipped with a fused silica chromatography column SP-2560 $100 \mathrm{~m} 0.25 \mathrm{~mm}$ internal diameter and a flame ionization detector. The parameters used in the program were: initial temperature of $180^{\circ} \mathrm{C}$ with an increase to $240^{\circ} \mathrm{C}$ $\left(10^{\circ} \mathrm{C} /\right.$ minute) and maintenance of this temperature for 10 minutes. The carrier gas was nitrogen, with a column flow of $0.6 \mathrm{~mL} / \mathrm{min}$ (Sabarense Mancini \& Son, 2003).
Performance and fatty acid profile data were submitted to polynomial regression analysis according to the different levels of vitamin $\mathrm{C}$ supplementation in the diet. The uniformity of the initial and final fish length was determined by the coefficient of variation, and the values were compared by Bartlett's test to evaluate homogeneity. The comparison of the fatty acid profile of fish that received vitamin C supplementation in the diet and those collected from the breeding fishpond was carried out using Dunnett's test. Data were analyzed by using the program SAEG 9.1 (2007).

\section{Results and Discussion}

The use of artificial aeration and a water heating system equipped with a thermostat enabled the maintenance of the quality of the water and appropriate conditions for the maintenance of the species, such that oxygen was always above $6 \mathrm{mgO}_{2} / \mathrm{L}$ and the temperature was $25^{\circ} \mathrm{C}$.

The results for weight gain, length and survival and cannibalism rates of fish conditioned to accept dry diets supplemented with vitamin C showed no significant differences (Table4) and were similar to those obtained by Luz et al. (2002).

The adopted diet might have provided favorable conditions for the feeding training of fingerlings, as recommended for carnivorous fish (Fox, 1975; De Angelis et al., 1979), and favored the survival and growth of fish fed all diets. The schedules for food supply, diet quality and cleanliness of the tanks at the end of each day may also have been crucial to the results. In this study, the use of saline water may have contributed to the welfare of animals, since the addition of salt in the water cultivation can reduce the effects of stress (Wurts, 1995; Carneiro \& Urbinati, 2001, Gomes et al., 2003).

Although it may be related to have decreased stress in several species of fish (Li \& Lovell, 1985; Sakakura et al. 1998; Petric et al., 2003; Moraes et al., 2003; Wang et al., 2006), vitamin C had no influence on this study, probably due to the good management practices which supported the welfare of the animals (Li \& Lovell, 1985; Sakakura et al., 1998; Petric et al., 2003; Moraes et al., 2003). This likely reduced stress on the fish reducing demand for vitamin C (Navarre \& Halver 1989).

It is also likely that the lack of an effect with vitamin C supplementation on weight gain and length, as well as the 
Table 4 - Weight and length gains, survival and cannibalism, initial and final length uniformity in giant trahira fingerlings in feed training with diets supplemented with vitamin C

\begin{tabular}{|c|c|c|c|c|c|c|c|}
\hline \multirow[t]{2}{*}{ Variable } & \multicolumn{7}{|c|}{ Level of vitamin C (mg/kg diet) } \\
\hline & 0.0 & 17.5 & 52.5 & 87.5 & 122.5 & 175.0 & 350.0 \\
\hline Weight gain $(g)^{1}$ & $0.14 \pm 0.05$ & $0.12 \pm 0.06$ & $0.11 \pm 0.07$ & $0.13 \pm 0.02$ & $0.14 \pm 0.04$ & $0.15 \pm 0.06$ & $0.15 \pm 0.06$ \\
\hline Lenght gain $(\mathrm{cm})^{1}$ & $0.23 \pm 0.05$ & $0.20 \pm 0.08$ & $0.15 \pm 0.10$ & $0.15 \pm 0.1$ & $0.15 \pm 0.05$ & $0.18 \pm 0.09$ & $0.15 \pm 0.0$ \\
\hline Survival $(\%)^{1}$ & $95.83 \pm 5.2$ & $93.06 \pm 7.35$ & $89.59 \pm 6.94$ & $96.53 \pm 3.4$ & $94.44 \pm 3.92$ & $91.67 \pm 3.20$ & $93.75 \pm 4.7$ \\
\hline Cannibalism $(\%)^{1}$ & $4.17 \pm 5.31$ & $6.25 \pm 7.97$ & $8.34 \pm 6.00$ & $3.47 \pm 3.4$ & $5.56 \pm 3.92$ & $8.34 \pm 3.20$ & $4.86 \pm 4.16$ \\
\hline Initial uniformity ${ }^{2}$ & $4.00 \pm 0.58$ & $3.80 \pm 0.48$ & $3.60 \pm 0.52$ & $3.85 \pm 1.0$ & $3.77 \pm 0.63$ & $4.00 \pm 0.80$ & $4.05 \pm 0.69$ \\
\hline Final uniformity ${ }^{3}$ & $6.30 \pm 1.00$ & $5.69 \pm 0.51$ & $4.30 \pm 0.50$ & $6.08 \pm 0.5$ & $5.31 \pm 0.75$ & $5.81 \pm 0.75$ & $5.79 \pm 0.61$ \\
\hline
\end{tabular}

${ }^{1}$ Not-significant $(\mathrm{P}>0.05) ;{ }^{2}$ Not-significant by Bartlett test $(\mathrm{P}<0.05) ;{ }^{3}$ Significant by Bartlett test $(\mathrm{P}<0.05)$.

rates of survival and cannibalism, was related to the shortterm administration of vitamin C (20 days), adopted in the methodology as proposed by Luz et al. (2002), who investigated 16 to 20 days of training in fingerlings of this species to dry diets. Similar results were observed in the larvae of Nile tilapia fed diets containing 0, 50, 100, 200, 400, 600,800 or $1000 \mathrm{mg}$ vitamin $\mathrm{C} / \mathrm{kg}$ feed for a period of 20 days (Toyama et al., 2000).

The levels of vitamin $\mathrm{C}$ supplementation in the diets affected $(\mathrm{P}<0.05)$ the uniformity of the fish in length (Table 4). Animals fed diets containing $52.5 \mathrm{mg}$ vitamin $\mathrm{C} / \mathrm{kg}$ diet showed greater uniformity. However, these results did not reflect improvements in performance or in lower rates of cannibalism.

For carnivorous species, heterogeneity in length of animals is seen as a major cause of cannibalism (Hecht \& Appelbaum, 1988; Katavic et al., 1989; Luz et al., 2000). Thus, it is possible that the greater uniformity in giant trahira fed $52.5 \mathrm{mg}$ vitamin $\mathrm{C} / \mathrm{kg}$ diet contributed to control cannibalism in subsequent phases of breeding.

The observed values of the rate of cannibalism in fish fed all diets can be considered low for the food training phase and it is likely to reflect the uniformity in the length of the fingerlings at the beginning of the experiment inasmuch as the greater the uniformity in length giant trahira, the lower the rate of cannibalism (Luz et al., 2000). The composition of foods and meeting the nutritional requirements of fish may also help prevent cannibalism (Fox, 1975; De Angelis et al., 1979).

Fish fed all diets showed no spinal curvature (lordosis) neither malformation of the operculum and mouth. Exophthalmos, erosion of fins and hemorrhagic areas were also not recorded, although vitamin $\mathrm{C}$ has a known effect on the formation of collagen and bone matrix (Divanach et al., 1996; Boglione et al., 2001; Ai et al., 2004). Similar results were reported for piavuçu fry (Leporinus obtusidens) fed diets containing $0,50,150,250,350,450,550,650,750$ and $850 \mathrm{mg}$ of vitamin C/kg (Mello et al., 1999).

The levels of vitamin $\mathrm{C}$ supplementation in the diets affected $(\mathrm{P}<0.05)$ the the monounsaturated fatty acids and eicosapentaenoic acid (C20:5n3) of fish (Table 5). However, the low value of the adjusted $\mathrm{R}^{2}(0.38)$ indicates that the regression equations do not satisfactorily explain the results obtained.

The sum of saturated and the sum of unsaturated fatty acids differed between fish collected from the breeding fishponds and those submitted to training feed with diets supplemented with vitamin C (Table 6). Fish collected in the ponds had the highest concentrations of saturated fatty acids compared to fish in the food training groups. However,

Table 5 - Fatty acid profile of fingerlings in feed training with diets supplemented with vitamin C

\begin{tabular}{|c|c|c|c|c|c|c|c|}
\hline \multirow[t]{2}{*}{ Fatty acid } & \multicolumn{7}{|c|}{ Level of vitamin C (mg/kg diet) } \\
\hline & 0.0 & 17.5 & 52.5 & 87.5 & 122.5 & 175.0 & 350.0 \\
\hline Myristic (C14:0) & 0.94 & 0.80 & 0.77 & 1.15 & 1.03 & 1.04 & 0.86 \\
\hline Palmitic (C16:0) & 19.58 & 18.19 & 17.92 & 18.66 & 18.39 & 19.26 & 17.74 \\
\hline Stearic (C18:0) & 13.45 & 13.77 & 13.81 & 12.45 & 12.98 & 11.67 & 13.71 \\
\hline$\sum$ satured & 38.08 & 39.49 & 38.32 & 38.79 & 38.67 & 38.03 & 38.63 \\
\hline Oleic (C18:1 9c) & 20.39 & 18.47 & 18.17 & 18.99 & 19.43 & 19.75 & 18.11 \\
\hline$\Sigma$ monounsatured $^{1}$ & 22.48 & 20.96 & 20.39 & 21.42 & 21.02 & 22.83 & 20.50 \\
\hline Linoleic (C18:2 n6) & 11.83 & 9.81 & 9.83 & 12.04 & 11.92 & 11.65 & 9.96 \\
\hline Arachidonic (C20:4 n6) & nd* & 0.25 & 0.33 & 0.46 & 0.32 & 0.21 & 0.22 \\
\hline Eicosapentanoic (C20:5 n3) ${ }^{2}$ & 5.94 & 6.50 & 6.47 & 5.04 & 5.22 & 5.28 & 5.91 \\
\hline Docosahexanoic (C22:6 n3) & 16.41 & 17.21 & 17.19 & 14.16 & 14.81 & 14.71 & 17.35 \\
\hline$\Sigma$ poliunsatured & 34.87 & 34.89 & 35.92 & 34.06 & 34.06 & 33.65 & 35.15 \\
\hline
\end{tabular}

${ }^{1} \mathrm{y}=-0.49 \mathrm{E}-07 \mathrm{x}^{3}+0.68 \mathrm{E}-04 \mathrm{x}^{2}-0.21 \mathrm{E}-01 \mathrm{x}+22.41\left(\mathrm{R}^{2}\right.$ adjusted $\left.=0.38\right)$

$2 \mathrm{y}=0.38 \mathrm{E}-05 \mathrm{x}^{2}-0.43 \mathrm{E}-02 \mathrm{x}+6.38\left(\mathrm{R}^{2}\right.$ adjusted $\left.=0.38\right)$.

* = not detectable. 
high concentrations of palmitic acid (C16: 0) were also observed in the lipid profile of fish that were in training diets free of vitamin C.

In fish collected from breeding fishponds, there was a higher amount of monounsaturated fatty acids. In those conditioned to diets supplemented with vitamin C, an increased amount of polyunsaturated fatty acids (Table 6) was observed. Among the polyunsaturated fatty acids, linoleic acids (C18: $2 \mathrm{n6}$ ), docosahexaenoic acid (C22: $6 \mathrm{n} 3$ ) and docosapentanoic (C20:5 n3) were found in the highest concentrations in fish fed diets containing vitamin C (Table 6).

These differences in lipid profile between fish collected from the breeding fishpond and fish fed diets containing vitamin $\mathrm{C}$ may be related to possible stressful situations that occurred in the breeding fishponds due to the transition between zooplankton and forage fish, as well as the oscillation in food availability caused by the difference in growth rate between giant trahira and forage fish. Stressful situations lead to aggression and persecution among the fish, requiring greater energy expenditure (Lefrançois, 2001), which can increase oxidation of polyunsaturated fatty acids to obtain energy (Chien \& Hwang, 2001). Stress can also cause formation of free radicals therefore changing the quantity and quality of fatty acids of the animal (Chen et al., 2004), as well as destabilizing lipid membranes (Chien \& Hwang, 2001).

Table 6 - Fatty acid profile of fingerlings in feed training with diets containing different levels of C vitamin and fish collected from nurseries

\begin{tabular}{|c|c|c|c|c|c|c|c|c|}
\hline \multirow[t]{2}{*}{ Fatty acid } & \multicolumn{7}{|c|}{ Level of vitamin C (mg/kg diet) } & \multirow[b]{2}{*}{ Control } \\
\hline & 0.0 & 17.5 & 52.5 & 87.5 & 122.5 & 175.0 & 350.0 & \\
\hline Myristic & 0.94 & 0.80 & 0.77 & 1.15 & 1.03 & 1.04 & 0.86 & 1.43 \\
\hline Stearic & 13.45 & 13.77 & 13.81 & 12.45 & 12.98 & 11.67 & 13.71 & 13.62 \\
\hline$\Sigma$ satured $^{1}$ & $38.08 \mathrm{~b}$ & $39.49 a$ & $38.32 b$ & $38.79 b$ & $38.67 b$ & $38.03 b$ & $38.63 \mathrm{~b}$ & $42.33 a$ \\
\hline Oleic $^{1}$ & $20.39 a$ & $18.47 b$ & $18.17 b$ & $18.99 b$ & $19.43 a$ & $19.75 a$ & $18.11 \mathrm{~b}$ & $20.84 a$ \\
\hline Arachidonic & NI & 0.25 & 0.33 & 0.46 & 0.32 & 0.21 & 0.22 & 0.45 \\
\hline Eicosapentanoic ${ }^{1}$ & $5.94 \mathrm{~b}$ & $6.50 \mathrm{~b}$ & $6.47 \mathrm{~b}$ & $5.04 \mathrm{~b}$ & $5.22 \mathrm{~b}$ & $5.28 \mathrm{~b}$ & $5.91 \mathrm{~b}$ & $4.53 a$ \\
\hline Docosahexanoioc $^{1}$ & $16.41 \mathrm{~b}$ & $17.21 \mathrm{~b}$ & $17.19 b$ & $14.16 \mathrm{~b}$ & $14.81 \mathrm{~b}$ & $14.71 b$ & $17.35 b$ & $10.18 \mathrm{a}$ \\
\hline$\Sigma$ polyunsatured $^{1}$ & $34.87 \mathrm{~b}$ & $34.89 b$ & $35.92 b$ & $34.06 \mathrm{~b}$ & $34.06 \mathrm{~b}$ & $33.65 b$ & $35.15 b$ & $25.09 \mathrm{a}$ \\
\hline
\end{tabular}

${ }^{1}$ Means followed by different letters in rows differ $(\mathrm{P}<0.05)$ from control by Dunnett test.

\section{Conclusions}

Vitamin C influences the uniformity of the final length of fingerlings during the food training phase and dietary supplementation with this vitamin alters the fatty acid profile in juvenile during training.

\section{References}

AI, Q.; KANGSEN MAI, K.; ZHANG, C. et al. Effects of dietary vitamin $\mathrm{C}$ on growth and immune response of Japanese seabass, Lateolabrax japonicus. Aquaculture, v.242, p.489-500, 2004.

Al-AMOUNDI, M.M.; El-NAKKADI, A.M.N.; El-NOUMAN, B.M. Evaluation of optimum dietary requirement of vitamin C for the growth of Oreochromis spilurus fingerlings in water from the Red Sea. Aquaculture, v.105, p.165-173, 1991.

BARCELLOS, L.J.G.; SOUZA, S.M.G.; WOEHL, V.M. Estresse em peixes: fisiologia da resposta ao estresse, causas e conseqüências (Revisão). Boletim Instituto de Pesca, v.26, n.1, p.99-111, 2000.

BARTON, B.A.; IWAMA, G.K. Physiological changes in fish from stress in aquaculture with emphasis on the response and effects of corticosteroids. Annual Review of Fish Diseases, v.1, p.3-26, 1991.

BILINSKI, E.; JONAS, R.E.E. Effect of coenzyme $A$ and L-carnitine on fatty acid oxidation in rainbow trout mitichondria. Journal of Fisheries Research, v.27, p.857-864, 1970 .

BOGLIONE, C.; GAGLIARDI, G.; SCARDI, M. et al. Skeletal descriptors and quality assessment in larvae and post-larvae of wild-caught and hatchery-reared gilthead sea bream (Sparus aurata L. 1758). Aquaculture, v.192, p.1-22, 2001.

CARNEIRO, P.C.F.; URBINATI, E.C. Salt as a stress mitigator of matrinxã Brycon cephalus (Günther), during transport. Aquaculture Research, v.32, p.297-304, 2001.

CHEN, R.; LOCHMANN, R.; GOODWIN, A. et al. Effects of dietary vitamins $C$ and $E$ on alternative complement activity, hematology, tissue composition, vitamin concentrations and response to heat stress in juvenile golden shiner (Notemigonus crysoleucas). Aquaculture, v.242, p.553-569, 2004.

CHIEN, R.G.; HWANG, D.F. Effects of thermal stress and vitamin $\mathrm{C}$ on lipid peroxidation and fatty acid composition in the liver of thornfish Terapon jarbua. Comparative Biochemistry Physiology, v.128, p.91-97, 2001.

DE ANGELIS, D.L.; COX, D.K.; CONTANT, C.C. Cannibalism and size dispersal in young-of-the-year largemouth bass: experimental model. Ecological Modelling, v.8, p.133-148, 1979.

DE BOECK, G.; VLAEMINCK, A.; VAN DER LINDEN, A. et al The energy metabolism of common carp (Cyprinus carpio) when exposed to salt stress: an increase in energy expenditure 
or effects of starvation? Physiological and Biochemical Zoology, v.73, p.102-111, 2000.

DIVANACH, P.; BOGLIONE, C.; MENU, B. et al. Abnormalities in finfish mariculture: an overview of the problem, causes and solutions. In: CHATAIN, B.; SAROGLIA, M.; SWEETMAN, J. et al. (Eds.) Seabass and seabream culture: problems and prospects. Verona, Italy: EAS International Workshop, 1996. p.45-66.

FALCON, D.R.; BARROS, M.M.; PEZZATO, L.E. et al. Lipídeo e vitamina $C$ em dietas preparatórias de inverno para tilápias-donilo. Revista Brasileira de Zootecnia, v.36, n.5, p.1462-1472, 2007a.

FALCON, D.R.; BARROS, M.M.; PEZZATO, L.E. et al. Physiological responses of nile tilapia, Oreochromis niloticus, fed vitamin c- and lipid-supplemented diets and submitted to low-temperature stress. Journal of the World Aquaculture Society, v.38, n.2, p.287-295, 2007b.

FOLCH, J.; LEES, M.; SLOANE-STANLEY, G.H. A simple method for the isolation and purification of total lipids from animal tissues. The Journal of Biological Chemistry, v.226, p.497-509, 1957.

FOX, L.R. Factors influencing cannibalism a mechanism of population limitation in the predator Notonecta Hoffmanni. Ecology, v.56, p.933-941, 1975.

FUJIMOTO, R.Y.; CARNEIRO, D.J. Adição de ascorbil polifosfato, como fonte de vitamina C, em dietas para alevinos de pintado, Pseudoplatystoma corruscans (Agassiz, 1829). Acta Scientiarum, v.23, n.4, p.855-861, 2001.

GOMES, L.C.; ARAUJO-LIMA, C.A.R.M.; ROUBACH, R. et al. Effect of fish density during transportation on stress and mortality of juvenile tambaqui Colossoma macropomum. Journal of the World Aquaculture Society, v.34, p.76-84, 2003.

HARTMAN, L.; LAGO, B.C.A. Rapid preparation of fatty methyl esters from lipids. Laboratory Practice, v.22, p.475-477, 1973

HECHT, T.; APPELBAUM, S. Observations on intraspecific aggression and coeval sibling cannibalism by larva and juvenile Clarios pwiepinus (Clariidae: Pisces) under controlled conditions. Journal of Zoology, v.214, p.21-44, 1988.

KATAVIC, I.; JUD-DUJAKOVIC, J.; GLAMUZINA, B. Cannibalism as a factor affecting the survival of intensively cultured sea bass (Dicentrurchus Iubrax) fingerlings. Aquaculture, v.77, p.135-143, 1989.

LALL, S.P.; LEWIS-MCCREA, L.M. Role of nutrients in skeletal metabolism and pathology in fish. Aquaculture, v.267, p.3-19, 2007.

LEFRANÇOIS, C.; CLAIREAUXA, G.; MERCIER, C. et al. Effect of density on the routine metabolic expenditure of farmed rainbow trout (Oncorhynchus mykiss). Aquaculture, v.195, p.269-277, 2001

LI, Y.; LOVELL, T. Elevated levels of dietary ascorbic acid increase immune response in channel catfish. The Journal of Nutrition, v.115, p.123-31, 1985

LIM, C.; YILDIRIM-AKSOY, M.; WELKER, T. et al. Growth performance, immune response, and resistance to Streptococcus iniae of Nile Tilapia, Oreochromis niloticus, fed diets containing various levels of vitamins $C$ and E. Journal of the world aquaculture society. v.41, n.1, p.35-48, 2010.

LIN, M-F.; SHIAU, S-Y. Dietary l-ascorbic acid affects growth, nonspecific immune responses and disease resistance in juvenile grouper, Epinephelus malabaricus. Aquaculture, v.244, p.215-221, 2005.

LUZ, R.K.; SALARO, A.L.; SOUTO, E.F. et al. Avaliação de canibalismo e comportamento territorial de alevinos de trairão (Hoplias lacerdae). Acta Scientiarum, v.22, n.2, p.465-469, 2000.
LUZ, R.K.; SALARO, A.L.; SOUTO, E.F. et al. Condicionamento alimentar de alevinos de trairão (Hoplias cf. lacerdae). Revista Brasileira de Zootecnia, v.31, n.5, p.1881-1885, 2002.

MELLO, R.F.; MOURA, M.A.M.; VIEIRA, I. et al. Suplementação da dieta de alevinos de piavuçu (Leporinus obtusidens) com vitamina C. Scientia Agrícola, v.56, n.4, p.1223-1231, 1999.

MORAES, J.R.E.; FREITAS, J.B.; BOZZO, F.R. et al. A suplementação alimentar com vitamina $C$ acelera a evolução do processo cicatricial em Piaractus mesopotamicus Holmberg, 1887. Boletim do Instituto de Pesca, v.29, p.57-67, 2003.

NAVARRE, O.; HALVER. J.E. Disease resistance and humoral antibody production in rainbow trout fed high levels of vitamin C. Aquaculture, v.79, p.207-221, 1989.

NATIONAL RESEARCH COUNCIL - NRC. Nutrient requirements of fish. Washington, D.C.: National Academy Press, 1993. $128 p$.

OKORIE, O.E.; KO, S.H.; GO, S. et al. Preliminary study of the optimum dietary ascorbic acid level in sea cucumber, Apostichopus japonicus (Selenka). Journal of the World Aquaculture Society, v.39, n.6, p.758-765, 2008.

PETRIC, M.C.; MARTINS, M.L.; ONAKA, E.M. et al. Suplementação alimentar com vitamina C potencializa a formação de macrófagos policariontes em Piaractus mesopotamicus Holmberg, 1887 (Osteichthyes: Characidae). Boletim do Instituto de Pesca, v.29, p.69-76, 2003.

REN, T.; KOSHIO, S.; UYAN, O. et al. Effects of dietary vitamin $\mathrm{C}$ on blood chemistry and nonspecific immune response of juvenile red sea bream, Pagrus major. Journal of the world aquaculture society, v.39, n.6, p.797-803, 2008.

ROSTAGNO, H.S.; ALBINO, L.F.T.; DONZELE, J.L. et al. Tabelas brasileiras para suínos e aves: composição de alimentos e exigências nutricionais. Viçosa, MG: Universidade Federal de Viçosa, 2005. 186p.

SABARENSE, C.M.; MANCINI FILHO, J. Efeito da gordura vegetal parcialmente hidrogenada sobre a incorporação de ácidos graxos trans em tecidos de ratos. Revista de Nutrição, v.16, n.4, p.399-407, 2003.

SAKAKURA, Y.; KOSHIO, S.; IIDA, Y. et al. Dietary vitamin C improves the quality of yellowtail (Seriola quinqueradiata) seedlings. Aquaculture, v.161, p.427-36, 1998.

STEFFEnS, W. Principles of fish nutrition. Chichester: Ellis Horwood, 1989. 384p.

TACON, A.G.J. Nutritional fish pathology: morphological signs of nutrient deficiency and toxicity in farmed fish. Rome: FAO, 1992. 75p. (Fisheries Technical Paper, 330).

TOYAMA, G.N.; CORRENTE, J.E.; CYRINO, J.E.P. Suplementação de vitamina $C$ em rações para reversão sexual da tilápia do Nilo. Scientia Agrícola, v.57, n.2, p.221-228, 2000.

UNIVERSIDADE FEDERAL DE VIÇOSA - UFV. SAEG - Sistema para Análises Estatísticas, versão 9.1. Viçosa, MG, 2007. (CD-ROM).

WANG, X.; KIM, K.W.; BAI, S.C. et al. Effects of the different levels of dietary vitamin $\mathrm{C}$ on growth and tissue ascorbic acid changes in parrot fish (Oplegnathus fasciatus). Aquaculture, v.215, p.203-211, 2003.

WANG, W.; WANG, Y.; WANG, A. Effect of supplemental L-ascorbyl-2 polyphosphate (APP) in enriched live food on the immune response of Penaeus vannamei exposed to ammonia-N. Aquaculture, v.256, p.552-557, 2006.

WEDEMEYER, G. Stress induced ascorbic acid depletion and cortisol production in two salmonid fish. Comparative Biochemistry Physiology, v.29, p.1247-1251, 1969.

WURTS, W.A. Using salt to reduce handling stress in chanel catfish. World Aquaculture, v.26, p.80-81, 1995. 